\title{
Changes in nitrate reductase activity and oxidative stress response in the moss Polytrichum commune subjected to chromium, copper and zinc phytotoxicity
}

\author{
Sanjib Kumar Panda ${ }^{1,2}$ and Shuvasish Choudhury ${ }^{2 *}$
}

${ }^{I}$ Research Institute for Bioresources, Okayama University, Kurashiki-7100046, Japan; ${ }^{2}$ Plant Biochemistry Laboratory, Department of Life Sciences, School of Life Sciences, Assam (Central)University, Silchar-788011, India; 'Corresponding author: shuvasish_au@indiatimes.com Received: 21/06/2004, Accepted: 16/05/2005

The main aim of this paper was to investigate the effect of chromium $(\mathrm{Cr})$, copper $(\mathrm{Cu})$ and zinc $(\mathrm{Zn})$ on nitrate reductase (NR) activity and oxidative stress responses in the moss Polytrichum commune. $\mathrm{Cr}, \mathrm{Cu}$ and $\mathrm{Zn}$ resulted in the inhibition of NR activity. A decline in total chlorophyll content was observed after 24 and $48 \mathrm{~h}$ of metal treatment. Accumulation of the metals showed a dose and time dependent increase. High accumulation of $\mathrm{Cu}, \mathrm{Cr}$ and $\mathrm{Zn}$ were seen in moss shoots after 24 and $48 \mathrm{~h}$ of treatment. Treatment of $\mathrm{Cr}, \mathrm{Cu}$ and $\mathrm{Zn}$ for 24 or $48 \mathrm{~h}$ resulted in the increase of malondialdehyde (MDA) content in moss shoots. The highest increase was observed in shoots under $\mathrm{Cu}$ treatment followed by $\mathrm{Cr}$ and $\mathrm{Zn}$. The MDA content was significantly higher after 48h. Antioxidant enzymes viz., catalase (CAT), guaiacol peroxidase (GPx), glutathione reductase (GR) and superoxide dismutase (SOD) were affected by elevated concentrations of the three metals. Increase in the activity of CAT, GR and SOD was seen after 24 and $48 \mathrm{~h}$ of treatment. GPx activity declined under $\mathrm{Cr}$ treatment. However, under $\mathrm{Cu}$ and $\mathrm{Zn}$, an increase in GPx was seen after $24 \mathrm{~h}$ and $48 \mathrm{~h}$ of treatment. For $\mathrm{Zn}$, the antioxidant efficiency was less affected as compared to $\mathrm{Cr}$ and $\mathrm{Cu}$. The response of Polytrichum commune to toxic concentrations of $\mathrm{Cr}, \mathrm{Cu}$ and $\mathrm{Zn}$ appears to induce oxidative damage as observed by the increase in MDA content and antioxidant metabolism.

Key words: antioxidants, chromium, copper, malondialdehyde, nitrate reductase, oxidative stress, Polytrichum commune, zinc

\begin{abstract}
Alterações na atividade da redutase do nitrato e respostas ao estresse oxidativo no musgo Polytrichum commune sujeito ao tratamento fitotóxico com cromo, cobre e zinco: O principal objetivo deste trabalho foi investigar o efeito do cromo (Cr), cobre $(\mathrm{Cu})$ e zinco $(\mathrm{Zn})$ sobre a atividade da redutase do nitrato $(\mathrm{RN})$ e respostas ao estresse oxidativo no musgo Polytrichum commune. $\mathrm{Cr}$, Cu e Zn causaram a inibição da atividade da RN. Uma diminuição na clorofila total foi observada após 24 e $48 \mathrm{~h}$ dos tratamentos com os metais. O acúmulo de metais mostrou ser dependente do aumento da dose e tempo. Observou-se grande acúmulo de $\mathrm{Cu}, \mathrm{Cr}$ e $\mathrm{Zn}$ nos brotos depois de 24 e 48 h dos tratamentos. Aqueles com $\mathrm{Cr}$, Cu e $\mathrm{Zn}$ por 24 ou 48 h resultou no aumento do conteúdo de malondialdeído (MDA) nos brotos. Verificou o maior aumento nos brotos tratados com $\mathrm{Cu}$, seguidos por $\mathrm{Cr}$ e Zn. O conteúdo de MDA foi significamente maior após $48 \mathrm{~h}$. Enzimas antioxidantes, como catalase (CAT), peroxidase do guaiacol (GPx), redutase da glutationa (GR) e dismutase do superóxido (SOD) foram afetadas por elevadas concentrações dos três metais. Aumentos nas atividades de CAT, GR e SOD foram observados após 24 e 48 h dos tratamentos. A atividade de GPx diminuiu com o tratamento de Cr, porém, com Cu e Zn, observou-se aumento de GPx após 24 h e 48 h do tratamento. Para o $\mathrm{Zn}$, a eficiência antioxidante foi menos afetada quando comparada ao $\mathrm{Cr}$ e $\mathrm{Cu}$. A resposta de Polytrichum commune a concentrações tóxicas de $\mathrm{Cr}, \mathrm{Cu}$ e $\mathrm{Zn}$ parece ser induzida pelo dano oxidativo quando observado através do aumento do conteúdo de MDA e metabolismo antioxidante.
\end{abstract}

Palavras-chave: antioxidantes, estresse oxidativo, cobre, cromo, malondialdeído, redutase do nitrato, zinco. 


\section{INTRODUCTION}

Plants need relatively small amounts of metals for their growth and soils harbor these metal ions either naturally or as a consequence of contamination. Soil contamination with heavy metals is now a worldwide problem, leading to agricultural losses and hazardous health effects as metals enter the food chain (Nellessen and Fletcher, 1993; Guo and Marschner, 1995; Salt et al., 1995). Copper, zinc and chromium are three broadline heavy metals that are phytotoxic above certain threshold levels (Neiborer and Richardson, 1980). Copper, which is relatively mild in character, is highly toxic to plants even at a micromolar range of exposure (Carbal, 2003). Copper can inhibit root elongation, block the photosynthetic electron transport chain and degrade chlorophyll (Quartacci et al., 2001; Patsikka et al., 2002). Copper can substitute co-factors of various enzymes and in turn degrade their activities (Nieboer and Richardson, 1980; Murphy et al., 1991; Quartacci et al., 2001). Copper can degrade the phospholipid structure and thereby alter the membrane structure and function (Quartacci et al., 2001). Chromium is an important polluting heavy metals that can induce severe damage to bacterial, plant and animal life. Zinc is one of the micronutrients essential for plant growth but is toxic to plants at higher concentrations and can retard plant growth and disrupt various essential physiological processes (Cakmak and Marschner, 1993; Chaney, 1993; Bhattacharjee and Mukherjee, 1994; Prasad et al., 1999; Panda et al., 2003). Toxic concentrations of zinc can retard growth and can initiate lipid peroxidation in plants (Prasad et al., 1999; Panda et al., 2003). In nature, chromium exists in two different forms, $\mathrm{Cr}$ (III) and $\mathrm{Cr}$ (VI) of which $\mathrm{Cr}$ (VI) is more toxic than $\mathrm{Cr}$ (III). Cr can induce phytotoxic symptoms in plants like morphological changes (Bassi et al., 1990), proline accumulation and alterations in antioxidant metabolism (Panda and Patra, 2000; Panda, 2003; Panda et al., 2003).

The presence of various reactive oxygen species (ROS) such as superoxide radicals $\left(\mathrm{O}_{2}^{-}\right)$, hydrogen peroxide $\left(\mathrm{H}_{2} \mathrm{O}_{2}\right)$, hydroxyl radicals $\left(\mathrm{OH}^{-}\right)$, etc., generated as a result of heavy metals can cause severe oxidative damage to biomolecules like lipids, proteins and nucleic acids (Alia et al., 1995; Gille and Singler, 1995). The presence of high concentrations of these ROS can thus disrupt the normal physiological and cellular functions (Asada, 1994; Gille and Singler, 1995). The presence of heavy metals in toxic concentrations can result in the formation of ROS, which can be initiated directly or indirectly by heavy metals. To counter the deleterious effects of the ROS, plants have evolved various enzymic and nonenzymic antioxidant systems, which can protect the plants from the toxic action of various ROS. The activities of these antioxidants are induced as a response to adverse biotic and abiotic stresses that can be considered as a general response to adverse conditions (Foyer et al., 1994). $\mathrm{Cr}, \mathrm{Cu}$ and $\mathrm{Zn}$ are known to induce ROS in cells. In comparison to $\mathrm{Zn}, \mathrm{Cr}$ has much higher catalytic activity in the Fenton reaction system but lower than $\mathrm{Cu}$ (see Panda and Choudhury, 2005 and references therein). However, this phenomenon is not well understood for $\mathrm{Cr}$ (VI). As a common consequence of ROS formation antioxidant metabolism is affected. $\mathrm{Cr}, \mathrm{Cu}$ and $\mathrm{Zn}$ can induce the activity of various antioxidant enzymes like CAT, GPx, SOD and GR and also non-enzymes like ascorbate and glutathione (Prasad et al., 1999; Panda, 2003; Panda et al., 2003; Choudhury and Panda, 2004a). Unlike $\mathrm{Cu}$ and $\mathrm{Zn}$, Cr cannot induce phytochelatin (PC) (Sanita di Toppi et al., 2004) and the defense mechanisms adopted by lower plants like mosses are less understood. However, metallothioneins (MTs) have a possible role in $\mathrm{Cr}$ detoxification in plants (Sanker et al., 2004; Panda and Choudhury, 2005). MTs in relation to $\mathrm{Cr}$ detoxification in plants have been investigated in sorghum where MT-like proteins are expressed under $\mathrm{Cr}$ (VI) stress (Sanker et al., 2004). A role of PC in counteracting metal toxicity has been reported in lichens Xanthoria parietina, Physcia adscedens (Fr.) H Oliver and Physconia grisea (Lam.) Poelt. (Pawlik-Skoworonska et al., 2002).

Interactions between bryophytes and heavy metals have been studied in many previous investigations (Sidhu and Brown, 1996; Bassile et al., 2001; Saxena et al., 2003; Choudhury and Panda 2004a; Panda and Choudhury 2005). Bryophytes have been frequently used as biomonitors of heavy metal pollution in many field studies (Tyler, 1990; Bargagli, 1998). They are especially suitable for the accumulation of heavy metals in view of their high surface-tovolume ratio and limited cuticle development (Brown, 1984). Beside this, they have high countergradient mechanisms for the accumulation of heavy metals in their tissue (Carginale et al., 2004). The mechanism of oxidative damage induced by heavy metals has been thoroughly studied in higher plants compared to that in bryophytes. However, there are very few studies dealing with oxidative stress in bryophytes (Panda 2003; Choudhury and Panda, 2004). In the present investigation we investigate the effect of $\mathrm{Cr}, \mathrm{Cu}$ and $\mathrm{Zn}$ on nitrate reducatse activity (NR), malondialdehyde (MDA) content and antioxidant response in moss Polytrichum commune. This investigation will highlight a better 
understanding of the mechanisms adopted by this moss species in response to toxic concentration of heavy metals. The study could be useful in determining oxidative stress parameters as toxicity bioindicators in mosses.

\section{MATERIAL AND METHODS}

Fresh samples of the moss Polytrichum commune were collected during the month of July 2002 and brought to the laboratory in clean polythene bags. Samples were cleaned in running tap water followed by three rinses in sterile distilled water. Shoots were placed in petri dishes with different concentrations of $\mathrm{Cr}, \mathrm{Cu}$ and $\mathrm{Zn}(0,0.01,0.1$ and $1 \mathrm{mM})$. The dishes were kept inside a growth chamber under continuous white light $\left(52 \mu\right.$ moles. $\mathrm{s}^{-1} \cdot \mathrm{m}^{-2}$, PAR $)$ at $22 \pm 2^{0} \mathrm{C}$. Shoots were harvested after 24 or $48 \mathrm{~h}$ of metal treatment for analysis.

Nitrate reductase (NR) activity was measured according to Srivastava (1980). Total chlorophyll content was measured spectrometrically by the method of Arnon (1949). The total Cr, $\mathrm{Cu}$ and $\mathrm{Zn}$ content in the shoot was estimated by drying known amounts of the shoot for $48 \mathrm{~h}$ at $70^{\circ} \mathrm{C}$. The dried shoots were digested with $5 \mathrm{~mL}$ concentrated nitric acid $\left(\mathrm{HNO}_{3}\right)$ at $100^{\circ} \mathrm{C}$ until the solution turned clear. The total sample volume was adjusted to $20 \mathrm{~mL}$ with distilled water. The amount of $\mathrm{Cr}, \mathrm{Cu}$ and $\mathrm{Zn}$ was then measured using an atomic absorption spectrometer (Perkin-Elmer, 3110, Germany).

Lipid peroxidation was measured as the amount of malondialdehyde (MDA) produced using the thiobarbituric (TBA) reaction as suggested by Heath and Packer (1968). $200 \mathrm{mg}$ of the moss shoot was homogenized with $2 \mathrm{~mL}$ of $0.1 \%$ trichloroacetic acid (TCA) and centrifuged at 10,000 $g_{\mathrm{n}}$ for $20 \mathrm{~min}$. To $1 \mathrm{~mL}$ of the supernatant extract, $1 \mathrm{~mL}$ of 20 $\%$ TCA containing $0.5 \%$ TBA and $0.001 \mathrm{~mL}$ butylated hydroxyl toluene (BHT) (a $4 \%$ solution in ethanol) were added. The mixture was heated at $95^{\circ} \mathrm{C}$ for $30 \mathrm{~min}$ and centrifuged at $10,000 g_{\mathrm{n}}$ for $15 \mathrm{~min}$. The absorbance was recorded at 532 $\mathrm{nm}$ and corrected by measurements at $600 \mathrm{~nm}$.

The moss tissues were homogenized in $0.1 \mathrm{M}$ phosphate buffer ( $\mathrm{pH}$ 6.8) in a pre-chilled mortar and pestle. The extract was centrifuged at $4^{0} \mathrm{C}$ at $12,000 g_{n}$ for $15 \mathrm{~min}$. The supernatant was used for the assay of Catalase (CAT) [EC 1.11.1.6], guaiacol peroxidase (GPX) [EC 1.11.1.7], superoxide dismutase (SOD) [EC 1.15.1.1] and glutathione reductase (GR) [EC 1.6.4.2]. GPX activity was assayed according to Chance and Maehly (1955). The $3 \mathrm{~mL}$ reaction mixture of GPX contained $0.1 \mathrm{M}$ phosphate buffer ( $\mathrm{pH}$ 6.8), guaiacol $(30 \mathrm{mM}), \mathrm{H}_{2} \mathrm{O}_{2}(30 \mathrm{mM})$ and $0.3 \mathrm{ml}$ of the enzyme extract. The rate of absorbance change was measured at
$420 \mathrm{~nm}$. The assay of SOD was carried out according to Giannopoltis and Ries (1977). The $3 \mathrm{~mL}$ assay mixture comprised of $79.2 \mathrm{mM}$ EDTA, $10.8 \mathrm{mM}$ tetraethylene diamine, $0.0033 \%$ bovine serine albumin, $6 \mathrm{mM}$ nitroblue tetrazolium (NBT), $600 \mu \mathrm{M}$ riboflavin and $0.2 \mathrm{~mL}$ enzyme extract. The reaction was initiated by placing the glass tubes between fluorescent bulbs (Philips 20W). By switching the light on and off, the reaction was started and terminated respectively. The increase in absorbance due to formazan formation was read at $560 \mathrm{~nm}$. GR was estimated according to Smith et al. (1988). The reaction mixture contained 0.2 $\mathrm{M}$ phosphate buffer ( $\mathrm{pH} 7.5$ ) together with $1 \mathrm{mM}$ EDTA, 3 $\mathrm{mM}$ 5,5'-dithiobis-2-nitrobenzoic acid (DTNB) in $0.01 \mathrm{M}$ potassium phosphate buffer ( $\mathrm{pH}$ 7.5), $2 \mathrm{mM}$ NADPH, $1 \mathrm{~mL}$ enzyme extract and distilled water to a final volume of 2.9 $\mathrm{mL}$. The reaction was initiated by adding $2 \mathrm{mM}$ oxidized glutathione or glutathione disulphide (GSSG). The increase in absorbance was measured at $412 \mathrm{~nm}$ at $25^{\circ} \mathrm{C}$.

The data presented are the mean of three separate experiments \pm SEM.

\section{RESULTS}

Figure 1 shows the effect of $\mathrm{Cr}, \mathrm{Cu}$ and $\mathrm{Zn}$ on total chlorophyll content and NR activity in shoots of $P$. commune after 24 or $48 \mathrm{~h}$ of treatment. NR activity was significantly reduced under treatment with $\mathrm{Cu}, \mathrm{Cr}$ and $\mathrm{Zn}$. After $24 \mathrm{~h}$, NR activity was reduced by $17.31 \%, 30.72 \%$ and $45 \%$ compared to the control at 1, 10 and $100 \mathrm{mM}$ of $\mathrm{Cr}$. Under $\mathrm{Cu}$ treatment, the inhibition was more pronounced. At 1, 10 and $100 \mathrm{mM}$ the NR activity reduced by $21.5 \%, 36 \%$ and $46 \%$ respectively with respect to the controls. Under $\mathrm{Zn}$ treatment NR activity was reduced by $11 \%, 19 \%$ and $21 \%$ with respect to controls at 1,10 and $100 \mathrm{mM}$ respectively. The inhibitory effect was significantly higher after $48 \mathrm{~h}$. The highest inhibition of NR activity was observed for $\mathrm{Cu}$ followed by $\mathrm{Cr}$ and $\mathrm{Zn}$. The total chlorophyll content was significantly affected by metal treatment. A decline in chlorophyll content was highest for $\mathrm{Cu}$, followed by $\mathrm{Cr}$ and $\mathrm{Zn}$. The effect of both $\mathrm{Cu}$ and $\mathrm{Cr}$ on the total chlorophyll content was pronounced after $24 \mathrm{~h}$. However, moss shoots under $\mathrm{Zn}$ treatment did not shown any significant decline at 1 and $10 \mathrm{mM}$ after $24 \mathrm{~h}$. After $48 \mathrm{~h}$ of treatment, a significant decline in total chlorophyll content was observed in moss shoots under $\mathrm{Cu}, \mathrm{Cr}$ and $\mathrm{Zn}$ treatment. Treatment with $\mathrm{Zn}$ for $48 \mathrm{~h}$ showed the least effect on the total chlorophyll content.

$\mathrm{Cr}, \mathrm{Cu}$ and $\mathrm{Zn}$ accumulation in moss shoots after 24 or $48 \mathrm{~h}$ is shown in figure 2. Highest concentrations in $\mathrm{Cr}, \mathrm{Cu}$ 
and $\mathrm{Zn}$ were observed at the 10 and $100 \mathrm{mM}$ treatments after $48 \mathrm{~h}$. The difference in the accumulation pattern for the three metals reflected the metal specificity of the moss. Unlike $\mathrm{Cu}$ and $\mathrm{Zn}$, no $\mathrm{Cr}$ could be detected in control moss shoots.

The variation in MDA content under $\mathrm{Cr}, \mathrm{Cu}$ and $\mathrm{Zn}$ treatment for 24 or $48 \mathrm{~h}$ in the moss shoot are shown in figure 3. MDA concentration was significantly higher under
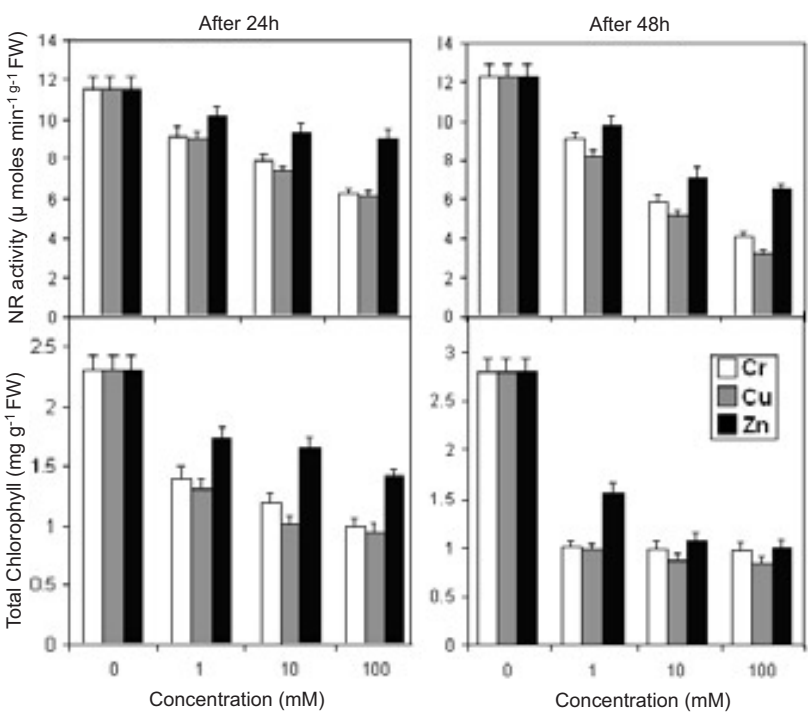

Figure 1. Effect of $\mathrm{Cr}, \mathrm{Cu}$ and $\mathrm{Zn}$ on nitrate reductase activity and total chlorophyll in shoots of the moss Polytrichum commune after 24 and $48 \mathrm{~h}$ of treatment. The data represent the mean of three separate experiments, \pm SE.

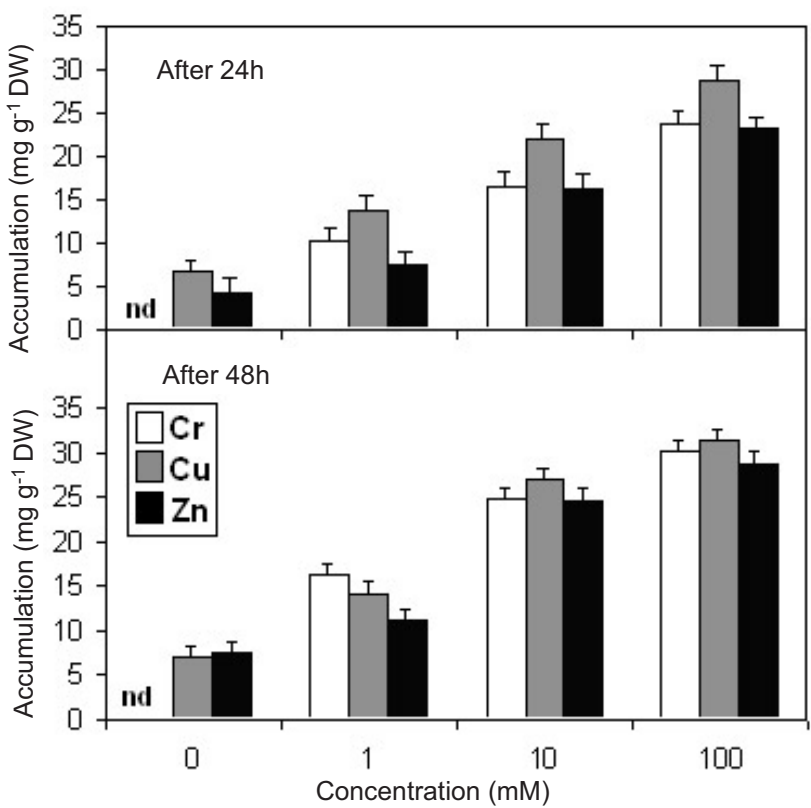

Figure 2. Accumulation of $\mathrm{Cr}, \mathrm{Cu}$ and $\mathrm{Zn}$ in shoots of the moss Polytrichum commune after 24 and $48 \mathrm{~h}$ of treatment. Legend as in figure 1. (nd: not detectable).
$\mathrm{Cu}$. After $24 \mathrm{~h}$, the MDA content increased by $227 \%, 323 \%$ and $518 \%$ respectively at 1,10 and $100 \mathrm{mM}$ with respect to controls. Much higher levels of MDA were observed after $48 \mathrm{~h}$, where about $328 \%, 500 \%$ and $698 \%$ increases were observed respectively at 1,10 and $100 \mathrm{mM}$ of $\mathrm{Cr}$ as compared to the controls. For $\mathrm{Cu}$ the MDA concentration was significantly higher and increased with concentration and treatment duration. However, under $\mathrm{Zn}$ treatment, the MDA content increased by $102 \%, 288 \%$ and $302 \%$ respectively at 1,10 and $100 \mathrm{mM}$ with respect to the controls. The increment in MDA content was much higher for $\mathrm{Cr}$ and $\mathrm{Cu}$-treated moss shoots. The increase in MDA content under the metal treatment can be correlated with an increase in treatment concentration and duration of treatment of the metals.

The changes in the antioxidant enzymes catalase (CAT), guaiacol peroxidase (GPx), glutathione reductase (GR) and superoxide dismutase (SOD) after 24 or $48 \mathrm{~h}$ of treatment is shown in figure 4 . The CAT activity increased upon metal treatment. CAT is an important enzyme involved in hydrogen peroxide $\left(\mathrm{H}_{2} \mathrm{O}_{2}\right)$ detoxification in plants. The increase in CAT activity was consistent both after 24 and $48 \mathrm{~h}$ of $\mathrm{Cr}$ treatment. Under $\mathrm{Cu}$ and $\mathrm{Zn}$ a similar trend was observed in CAT activity. There were differences in GPx activity in moss shoots under metal treatment. For Cr, GPx showed increased activity after $24 \mathrm{~h}$, but declined after $48 \mathrm{~h}$ of treatment. This

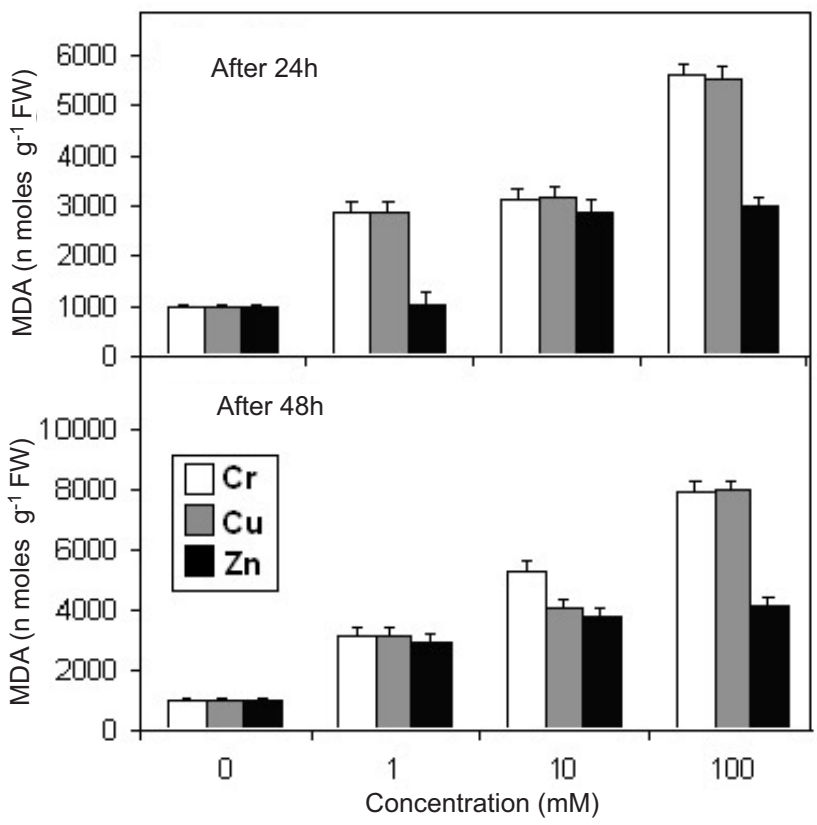

Figure 3. Changes in malondialdehyde (MDA) content in shoots of the moss Figure 3. Polytrichum commune after $24 \mathrm{~h}$ and $48 \mathrm{~h}$ of $\mathrm{Cr}, \mathrm{Cu}$ and $\mathrm{Zn}$ treatment. Legend as in figure 1. 

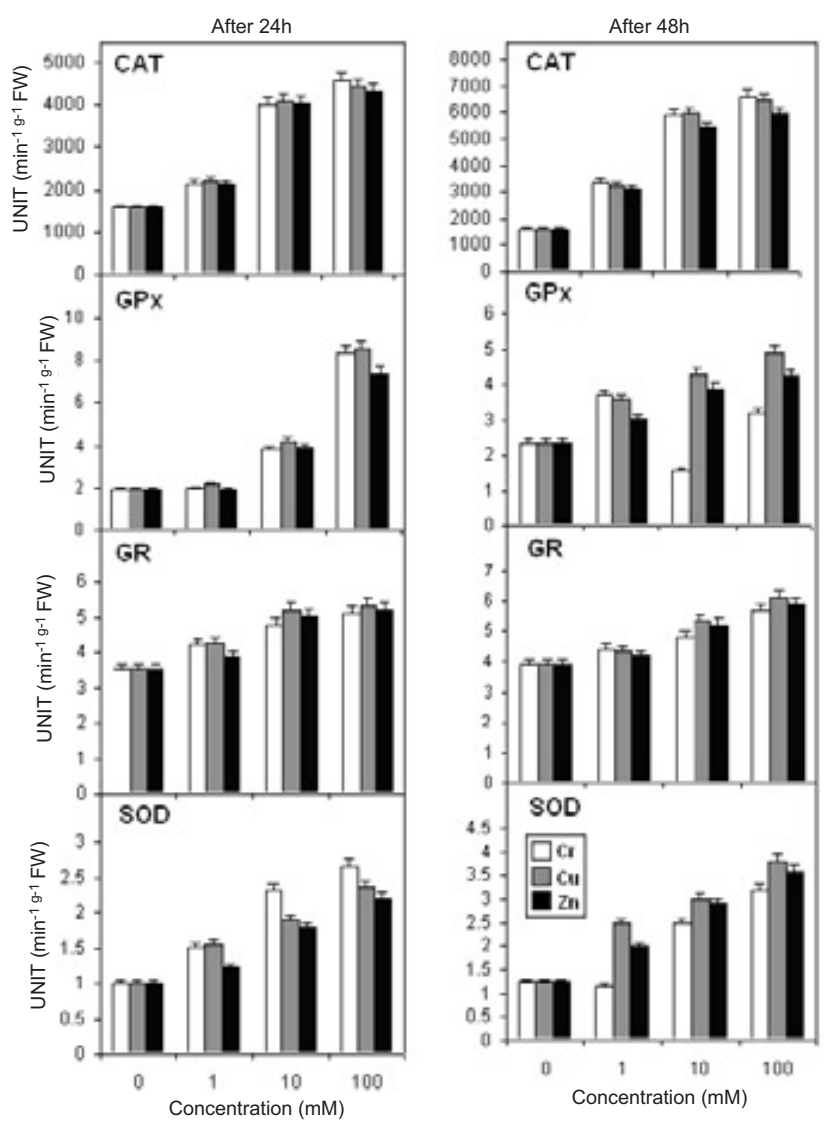

Figure 4. Changes in the activities of antioxidant enzymes CAT, GPx, GR and SOD in shoots of the moss Polytrichum commune after 24 and $48 \mathrm{~h}$ of $\mathrm{Cr}, \mathrm{Cu}$ and $\mathrm{Zn}$ treatment Legend as in figure 1.

was completely different for $\mathrm{Cu}$ and $\mathrm{Zn}$-treated moss shoots, where an increase in GPx activity was recorded after 24 and $48 \mathrm{~h}$ of treatment. Increase in GR and SOD activity was seen in moss shoots after 24 and $48 \mathrm{~h}$ of treatment.

\section{DISCUSSION}

We observed that elevated concentrations of $\mathrm{Cr}, \mathrm{Cu}$ and $Z n$ can induce oxidative stress in moss $P$. commune. The effect of the metals on NR activity was inhibitory. The inhibition of $\mathrm{NR}$ activity by $\mathrm{Cr}, \mathrm{Cu}$ and $\mathrm{Zn}$ affected the ammonia assimilation pathway. Panda and Patra (1998) reported increases in $\mathrm{NR}$ activity under $\mathrm{Cr}$ treatment in wheat seedlings. However, this was only possible in wheat seedlings when nitrate and ammonium ions were supplemented in the growth media containing the lower $(0.001 \mathrm{mM})$ concentration of $\mathrm{Cr}$. The lower $\mathrm{Cr}$ concentration containing nitrogen supplement in the medium as reported by Panda and Patra (1998) in wheat might have helped in de novo synthesis of NR isoenzymes. For high concentrations of metals like $\mathrm{Cr}, \mathrm{Cu}$ and $\mathrm{Zn}$ the $\mathrm{SH}$-group of the NR enzyme is affected resulting in a decline in its activity. Inhibition of NR activity has been reported for higher plants under $\mathrm{Zn}$ and $\mathrm{Pb}$ toxicity (Mathys, 1975; Jain and Garde, 1997; Luna et al., 2000).

As shown in figure 1, the total chlorophyll content declined under metal treatment. A decline in total chlorophyll content has been reported in many plants under heavy metal stress (Panda and Patra, 1998; Panda et al., 2003; Choudhury and Panda, 2004a). Chlorophyll pigments are one of the main sites of heavy metal injury in plants. A significant decline as observed for $\mathrm{Cr}$ and $\mathrm{Cu}$ reflects the inhibitory effect of these metals on pigment biosynthesis which might be a metal specific action. Zn was found to be the least effective in degrading chlorophyll biosynthesis. Degradation of chlorophyll content has been previously reported in the case of $\mathrm{Cr}, \mathrm{Cu}$ and Zn (McGrath, 1982; Panda and Patra, 1998; Vajpayee et al., 2000; Panda et al., 2003).

It is well established that bryophytes are hyperaccu-mulators of heavy metals (Tyler, 1991; Bargagli, 1998). Increases in accumulation of $\mathrm{Cr}, \mathrm{Cu}$ and $\mathrm{Zn}$ were seen in moss shoots after 24 and $48 \mathrm{~h}$ of treatment. The accumulation of these metals in shoots occurred in a time and dose dependent manner. Mosses have high countergradient mechanisms by which they accumulate significant concentrations of metals in their tissues (Cargainale et al., 2004). The high metal accumulating capacity is also attributed to a high surface-to-volume ratio (Brown, 1984). Similar accumulation of heavy metals has been reported for other mosses and liverworts (Brown, 1984; Sidhu and Brown, 1996; Choudhury and Panda, 2004a).

The elevation in MDA content in moss shoot clearly reflects cell wall damage. MDA is a product of lipid peroxidation induced by ROS. Lipid peroxidation induced by ROS has been reported in plants under heavy metal stress. Participation of $\mathrm{Cr}$ in ROS generation, unlike $\mathrm{Cu}$, is well understood. It is believed that the $\mathrm{Cr}$ ion in its trivalent and divalent oxidation states can enter the Fenton reaction (Strile et al., 2003; Panda and Choudhury, 2005). However, for the hexavalent form of $\mathrm{Cr}$ the mechanism of ROS generation is not well understood. The increase in MDA content reflects oxidative stress in the moss. Similar observations were reported in plants under heavy metals like $\mathrm{Cr}, \mathrm{Cu}, \mathrm{Zn}, \mathrm{Pb}, \mathrm{As}$ and $\mathrm{Cd}$ (Panda et al., 2003; Choudhury and Panda, 2004a,b; Cuny et al., 2004; Panda, 2003; Sanita di Toppi et al., 2004)

The response of the antioxidant enzymes viz. CAT, GPx, GR and SOD in moss shoot under $\mathrm{Cr}, \mathrm{Cu}$ and $\mathrm{Zn}$ treatment followed a similar pattern. CAT, GR and SOD activity in- 
creased upon metal treatment while GPx activity increased after $24 \mathrm{~h}$ of $\mathrm{Cr}$ treatment but declined after $48 \mathrm{~h}$. However, for $\mathrm{Cu}$ and $\mathrm{Zn}$, an increase in GPx activity was seen after 24 or $48 \mathrm{~h}$ of treatment. CAT and GPx are important enzymes involved in the detoxification of hydrogen peroxide (Scandalios, 1993). The variation in the activity of GPx under Cr, $\mathrm{Cu}$ and $\mathrm{Zn}$ revealed a metal specific response of the enzyme in moss shoot. GR is involved in detoxification of hydrogen peroxide in the chloroplast and mitochondria (Foyer and Halliwell, 1976). Increase in GR activity along with CAT and GPx in the moss shoot reflected the constant detoxification of hydrogen peroxide. Such a response was reported for Oryza sativa, Brassica juncea under Zn treatment (Prasad et al., 1999). However, Panda (2003) and Choudhury and Panda (2004a,b) reported inhibition of CAT, GPx and GR activities in the moss Taxithelium nepalense (Schwaegr.) Broth. and in O. sativa $\mathrm{L}$. roots under $\mathrm{Cr}, \mathrm{Zn}, \mathrm{Pb}, \mathrm{As}, \mathrm{Cd}, \mathrm{Cr}$ and $\mathrm{Cu}$ toxicity. The SOD activity was higher in metal-treated shoots. SOD is an important enzyme involved in scavenging the superoxide radical (Panda, 2002). The increase in SOD activity under metal treatments indicates the constant detoxification of the superoxide radical that might have been generated. Increase in SOD activity was reported earlier in the moss $T$. nepalense under $\mathrm{Pb}, \mathrm{Cr}, \mathrm{Zn}, \mathrm{Cu}$ and As toxicity and also in the lichen Diploschistes muscorum (Scop.) R. Sant. under $\mathrm{Zn}, \mathrm{Pb}$ and Cd toxicity (Cuny et al., 2004). However, these antioxidant enzymes have been little studied in lower plants like mosses and lichens (Panda, 2003; Choudhury and Panda, 2004; Cuny et al., 2004; Sanita do Toppi et al., 2004). The antioxidant metabolism in moss shoots indicated constant detoxification of ROS under $\mathrm{Cr}, \mathrm{Cu}$ and $\mathrm{Zn}$ stress.

In conclusion, the investigation highlighted the involvement of $\mathrm{Cr}, \mathrm{Cu}$ and $\mathrm{Zn}$ in inducing oxidative stress in the moss $P$. commune reflected by the physiological disturbances induced by the heavy metals. The physiological disturbances like increase in MDA content, decline in total chlorophyll content and reduction in NR activity clearly indicated the toxic effects of the metal. However, activation of the antioxidant metabolism under metal stress reflected constant detoxification of ROS in moss cells. Thus, oxidative stress parameters can be considered as useful biomarkers of environmental pollution.

\section{REFERENCES}

Alia, Prasad KVSK, Pardha Saradhi P (1995) Effect of zinc on free-radicals and proline in Brassica juncea and Cajanus cajan. Phytochemistry 39:45-47.
Arnon DI (1949) Copper enzyme in isolated chloroplast, polyphenol oxidase in Beta vulgaris. Plant Physiol. 24: $1-15$.

Asada K (1994) Production and action of active oxygen species in photosynthetic tissue. In: Foyer $\mathrm{CH}$, Mullmeaux PM (eds), Causes of Photooxidative Stress and Amelioration of Defense System in Plants, pp.77-107. CRC Press, Boca Raton, FL.

Bargagli R (1998) Mosses as passive and active biomonitors of trace elements. In: Bargagli R (ed), Trace Elements in Terrestrial Plants, pp.207-236. Springer-Verlag, Berlin.

Basile A, Cogoni AE, Bassi P, Fabriz E, Sorbo S, Giordano S, Castaldo Cobianchi R (2001) Accumulation of $\mathrm{Pb}$ and $\mathrm{Zn}$ in gametophyte and sporophyte growth of the moss Funaria hygrometrica (Funariales). Ann. Bot. 87:537-543.

Bassi M, Grazia Corradi M, Realini M (1990) Effect of Cr (VI) on two fresh water plants Lemna minor and Pistia stratores, 1. Morphological observation. Cytobios 62:27-38.

Bhattacharjee S, Mukherjee AK (1994) Influence of cadmium and lead on physiological and biochemical response of Vigna unguiculata (L.) Walp. Seedlings. I. Germination behaviour, total protein, proline and protease activity. Pollut. Res. 13:269-277.

Brown DH (1984) Uptake of mineral elements and their use in pollution monitoring. In: Dyer AF, Duckett JG (eds), The Experimental Biology of Bryophytes, pp.229-255. Academic Press, NY.

Cabral JP (2003) Copper toxicity in five Parmelia lichens in vitro. Environ. Exp. Bot. 49:237-250.

Cakmak I, Marschner H (1993) Effect of zinc nutritional status on superoxide radical and hydrogen peroxide scavenging enzymes in bean leaves. In: Barrow NJ (ed), Plant Nutrition - from Genetic Engineering to Field Practice, pp.133-137. Kluwer Academic Publishers, Dordercht.

Carginale V, Sorbo S, Capasso C, Trinchella F, Cafiero G, Basile A (2004) Accumulation, localization and toxic effects of cadmium in the liverwort Lunularia cruciata. Protoplasma 223:53-61.

Chance B, Maehly AC (1955) Assay of catalase and peroxidase. Meth. Enzymol. 2:746-778.

Chaney RL (1993) Zinc phytotoxicity. In: Robson AD (ed), Zinc in Soil and Plants, pp.135-150. Kluwer Academic Publishers, Dordercht.

Choudhury S, Panda SK (2004a) Induction of oxidative stress and ultrastructural changes in moss Taxithelium nepalense (Schwaegr.) Broth. under lead ( $\mathrm{Pb}$ ) and arsenic (As) phytotoxicity. Curr. Sci. 87:342-348.

Choudhury S, Panda SK (2004b) Membrane deterioration and biochemical lesions in Oryza sativa L. under cadmium toxicity. In: Borah RC, Talukdar A, Kataky JCS, Unni BG, Modi MK, Deka PC (eds), Bioprospecting of Commercially Important Plants (Proceedings National Symposium, Indian Society of Agricultural Biochemists, Jorhat Chapter, 2003), pp.224-229. Assam Agricultural University and Indian Society od Agricultural Biochemists, Jorhat, India.

Cuny D, Van Haluwyn C, Shirali P, Zerimech F, Jerome L, Haguenoer JM (2004) Cellular impact of metal trace 
elements in terricolous lichen Diploschistes muscorum (Scop.) R. Sant.- Identification of oxidative stress biomarker. Water Air Soil Pollut. 152:55-69.

Foyer C, Halliwell B (1976) The presence of glutathione and glutathione reductase in chloroplast: a proposed system for ascorbic metabolism. Planta 133:21-25.

Foyer CH, Lelandies M, Kunert KJ (1994) Photooxidative stress in plants. Physiol. Plant. 92:696-717.

Giannopololitis CN, Ries SK (1977) Superoxide dismutase. I. Occurrence in higher plants. Plant Physiol. 59:309-314.

Gille G, Sigler K (1995) Oxidative stress and living cells. Folia Microbiol. 40:131-152.

Guo Y, Marschner, H (1995) Uptake, distribution and binding of cadmium and nickel in different plant species. J. Plant Nutr. 18:2691-2706.

Heath RL, Packer L (1968) Photoperoxidation in isolated chloroplast, I. Kinetics and stoichiometry of fatty acid peroxidation. Arch. Biochem. Biophys. 125:189-198.

Jain M, Gadre RP (1997) Inhibition of nitrate reductase activity by lead in greening bean leaf segments, a mechanistic approach. Ind. J. Plant Physiol. 2:5-9.

Luna CM, Casano LM, Trippi VS (2000) Nitrate reductase is inhibited in leaves of Triticum aestivum treated with high level of copper. Physiol. Plant. 101:103-108.

Mathys TM (1975) Enzymes of heavy metals resistant and non-resistant populations of Silene cucubalus and their interaction with some heavy metals in vitro and in vivo. Physiol. Plant. 33:161-165.

McGrath SP (1982) The uptake and translocation of trivalent and hexavalent chromium and effects on the growth of oat in flowering nutrient solution and in soil. New Phytol. 92: 381-390.

Murphy AS, Eisingter WR, Shaff JE, Kochian LV, Taiz L (1999) Early copper induced leakage from Arabidopsis seedlings is mediated by iron channels and coupled to citrate efflux. Plant Physiol. 121:1375-1382.

Nellessen H, Fletcher JS (1993) Assessment of published literature on uptake, accumulation and translocation of heavy metals in vascular plants. Chemosphere 9:16691680.

Nieboer E, Richardson DHS (1980) The replacement of non-descript term "heavy metals" by a biologically and chemically significant classification of metal ions. Environ. Pollut. 1:3-26.

Panda SK, Choudhury S (2005) Chromium stress in plants. Braz. J. Plant Physiol. 17:131-136.

Panda SK (2003) Heavy metal phytotoxicity induces oxidative stress in a moss, Taxithelium sp. Curr. Sci. 84:631-663.

Panda SK, Chaudhury I, Khan MH (2003) Heavy metals induce lipid peroxidation and affect antioxidants in wheat leaves. Biol. Plant. 46:289-294.

Panda SK (2002) The biology of oxidative stress in green cells: a review. In: Panda SK (ed), Advances in Stress Physiology of Plants, pp.1-13. Scientific Publishers, India.

Panda SK, Patra HK (1998) Role of nitrate and ammonium ions on chromium toxicity in developing wheat seedlings. Proc. Nat. Acad. Sci. India 70:75-80.
Panda SK, Patra HK (2000) Does chromium (III) produce oxidative damage in excised wheat leaves. J. Plant Biol. 27:105-110.

Patsikka E, Kairavuo M, Sersen F, Aro E-M, Tyystjarvi E (2002) Excess copper predisposes photosystem II to photoinhibition in vivo by outcompeting iron and causing decrease in leaf chlorophyll. Plant Physiol. 129:13591367.

Pawlik-Skowronska B, Sanita di Toppi L, Favali MA, Fossati F, Pirszel J, Skowronski T (2002) Lichen respond to heavy metals by phytochelatin synthesis. New Phytol. 156:95102.

Prasad KVSK, Pardha Saradhi P, Sharmila P (1999) Concerted action of antioxidant enzymes and curtailed growth under zinc toxicity in Brassica juncea. Environ. Exp. Bot. 42: $1-10$.

Quartacci MF, Cosi E, Navari-Izzo F (2001) Lipids and NADPH dependent superoxide production in plasma membrane vesicle from roots of wheat grown under copper deficiency or excess. J. Exp. Bot. 52:77-84.

Salt DE, Smith RD, Raskin I (1995) Phytoremedation. Annu. Rev. Plant Physiol. Plant Mol. Biol. 49:643-668.

Sanita di Toppi L, Musetti R, Marabottini R, Corradi MG, Vattuone Z, Augusta M, Badiani M (2004) Responses of Xanthoria parietina thalli to environmentally relevant concentrations of hexavalent chromium. Func. Plant Biol. 31:329-338.

Saxena A, Saxena DK, Srivastava HS (2003) The influence of glutathione on physiological effects of lead and its accumulation in moss Sphagnum squarrosum. Water Air Soil Pollut. 143:351-361.

Scandalios JG (1993) Oxygen stress and superoxide dismutase. Plant Physiol. 101:7-12.

Shanker AK, Djanaguiraman M, Sudhagar R, Jayram K, Pathmanabhan G (2004) Expression of metallothioneins 3-like protein mRNA in sorghum cultivars under chromium (VI) stress. Curr. Sci. 86:901-902.

Sidhu M, Brown DH (1996) A new laboratory technique for studying the effect of heavy metals on bryophyte growth. Ann. Bot. 78:711-717.

Smith IK, Vierhgeller TL, Throne CA (1988) Assay of glutathione reductase in crude tissue homogenate using 5, 5'-dithiobis (2-nitrobenzoic) acid. Anal. Biochem. 175: 408-413.

Srivastava HS (1980) Regulation of nitrate reductase activity in higher plants. Phytochem. 19:725-733.

Strile M, Kolar J, Selih VS, Kocar D, Pihlar B (2003) A comparative study of several transition metals in Fenton like reaction system at circum-neutral pH. Acta Chim. Slov. 50:619-632.

Tyler G (1990) Bryophytes and heavy metals: a literature review. Bot. J. Linn. Soc. 104:231-253.

Vajpayee P, Tripati RD, Rai UN, Ali MB, Singh SN (2000) Chromium accumulation reduces chlorophyll biosynthesis, nitrate reductase activity and protein content of Nymphaea alba. Chemosphere 41:1075-1082. 